\title{
The Social Sense of Geological Literacy
}

\author{
HÉCTOR LUIS LACREU \\ Departamento de Geología, Universid ad Nacional de San Luis, Argentina \\ lacreu@gmail.com
}

\begin{abstract}
Ways and methodologies to teach geology are widely debated and are frequent topics in geoscientific discussion, whereas there is much less attention to the subject of geological literacy. It is more and more frequent to hear complaints by university teachers regarding the deficient geological knowledge of incoming university students, and this is especially the case in Argentina's universities. Teachers simply characterize the problem affirming: "the students do not know anything about geology" or "in high school nobody taught them geology". Additionally, most geologists consider that it is not their problem and consider secondary teachers as uniquely responsible. Nevertheless, the matter is more complicated than this and deserves a different approach for resolution. In this contribution I table reflections on the need to address the lack of preparation and the scarcity of geological knowledge in terms of geological literacy, rather than in terms of teaching geology.
\end{abstract}

\section{INTRODUCTION}

I nadequate geological knowledge not only affects students in universities, but also the majority of citizens who finish their secondary studies without having learned any basic geological notions. The most worrisome aspect in this situation is that this ignorance also characterizes politicians, technicians, journalists and science communicators, who act and give opinions on natural resources and environmental problems, without any comprehension as to causes and effects of the issues, thereby contributing to the increase in confusion in the public.

For too many years, the same opinions on this matter have been repeated, by using two key concepts, "knowledge" and "teaching", and by omitting the concept of "learning", while the three concepts should be all considered simultaneously within the framework of the real conditions in which they interact.

Without doubt there are efforts to improve this state of affairs, but for the sake of brevity I will make some generalizations, that in some cases may seem improper and incorrect. Therefore, my apologies for those who will feel slighted and my encouragement to them to spread their achievements through publications that are accessible to educators.
Improving teaching of geology requires an adequate characterization of the problem, by focusing on the sense of geological learning and knowledge. This represents a great challenge for the geological community, both in terms of understanding the concept of geological literacy and in terms of intervention with concrete actions in primary, secondary and university studies.

Another challenge is to improve the approach to the problem, given the complexity to intervene in these domains, the lack of individuals who are expert in the subject, the conflicts of interests and the resistance of some teachers to introduce changes in their usual practices.

In that sense, we could list other challenges, but I will do so later, after a few reflections on scientific literacy in general and geological literacy in particular.

\section{SOME NOTIONS ON SCIENTIFIC LITERACY}

The term "literacy" was first used in the late nineteenth century to indicate the capability to read and write. It is one of those self-defining terms, such as "freedom", "justice", "happiness", which we incorporate in our culture for their content, needed qualities and desirable attributes (Braslavsky, 2003). Since then, the 
term "literacy" has been rephrased and a consensus has been built on the meaning of Scientific and Technological Literacy (ACT in Spanish). It "designates a type of knowledge, skills or competences that in our technical-scientific world correspond to what literacy was in the last century" (Fourez, 1997: 15). In addition, the term "literacy" propitiates a more complex culture that gives value to both the pertinence and the adequate use of knowledge as an ethical commitment to reflect on the social and political consequences of its application.

Within this orientation, it has been pointed out that "given the complexity of present and future global challenges, higher education has the social responsibility to advance our understanding of multifaceted problems that imply social, economic, scientific and cultural aspects, as well as our capability of addressing them. Higher education should take on social leadership in global knowledge-building to address global challenges, including food security, climate change, water management, intercultural dialogue, renewable energy and public health" (UNESCO, 2009).

As a result, we can assume that scientific literacy is necessary to improve the quality of citizen participation in decision-making, in economic policies developed in different sectors (for example: legislative projects at municipal, provincial and/ or national scale), as well as in the public hearings convened when works that have an impact on the environment are carried out. Such timely and relevant participation requires from "citizens more than a very high level of knowledge, the linking of a minimum of specific knowledge, perfectly accessible to citizens, with global approaches and ethical considerations that don't require any specialization." (Gil y Vilches, 2003).

\section{DIMENSIONS OF GEOLOGICAL LITERACY}

Geological literacy is a multidimensional challenge and requires new curricular proposals overcoming traditional teaching, restricted only to conceptual and methodological geological contents. In this sense, it is recommended to incorporate other dimensions such as the history of geological ideas, epistemology, the nature of geology, specific techniques and methods, professional practices, and their role in personal and social life (adapted from Bybee, 1997; quoted in Gil-Pérez et al., 2005).

In this approach, it can be pointed out that geological curricula for all the citizens should have the following common elements (adapted from Marco, 2000):

- Practical geological literacy that allows us to make use of geological knowledge in daily life, in order to improve living conditions, as well as features, natural resources and risks of our environment.

- Civic geological literacy, so that all people can socially intervene in political decisions with different criteria, including ethical and scientific criteria.

- Cultural geological literacy that debates the meaning of science and technology and their impact on the social structure.

In short, geological literacy in a broad sense should integrate practical literacy, civic literacy and cultural literacy for citizens in general.

\section{GEOLOGICAL LITERACY IN EDUCATIONAL LEVELS}

The change from "geological teaching" to "geological literacy" implies both an expansion of content and a new approach, centered on learning, in which the concepts reduce their traditional role, to share it with skills and attitudes in the use of such concepts. This approach requires new didactics, appropriate to each educational level, to the "geological horizon" that surrounds each institution, to the resources available, and so on. All these elements configure a set of specific needs that are subjects of study, creation and research of a new disciplinary field called the "Geolodactics" (Lacreu, 2012).

In the social imaginary, in the general educational regulations and in the specific curricular models, it is expected that pre-university education should be aimed at training citizens, simultaneously training for work insertion and propaed eutic training.

In Argentina, with regards to the primary level of education, it is perceived that "practical geo- 
logical literacy" includes sufficient geological contents. However, sequencing and graduality are considered inadequate, whereas didactic strategies often ignore fieldwork and the CTS approach (Lacreu, 2015).

On the other hand, in the Argentine secondary educational level, the geological contents are almost null within the NAP (Priority Learning Nucleus) of Natural Sciences for the common cycle of all high schools. They are also absent in most of the orientated high schools, except for the orientations in "Natural Sciences" and "Environment", in which the new specific curricular space of "Earth Sciences" was created. However, it is not possible to develop geological contents in depth, since the necessary prerequisites do not exist (Lacreu, 2014). In relation to the secondary educational level, it is important to note an important contribution on Literacy in Earth Sciences made by a group of Spanish colleagues (Pedrinaci et al., 2013) who managed to synthesize 5 objectives and 10 key ideas that constitute an indispensable guide to review the Argentine curricula.

With reference to the university level, geology careers offer an adequate higher education in specific geological aspects, far surpassing the needs of "practical geological literacy". However, there are shortcomings in "civic geological literacy" and "cultural geological literacy", save some exceptions, that persist throughout the formative stage, weakening the integral training and, therefore, the professional profile of geologists, as required by the new regulations in force since 2008. Precisely for this reason, I share the great concern that exists in the international arenas where the problem of higher education is discussed.

In my experience of more than 30 years in university teaching, in divulgation activities and training of teachers I have been able to witness the insufficient literacy of university aspirants. Indeed, this is manifested in the scarce geological and mathematical knowledge and in a notable deficit in the capability of readingcomprehension as well as in communicative competencies. For these reasons, the national universities adopted support policies to reinforce such instrumental skills and to reduce the number of students that dropout. In addition, geology courses include subjects such as "In- troduction to Geology" and courses on reading, comprehension and writing of scientific texts, as a way of compensating for the deficit in the "practical geological literacy" of entrants.

Unfortunately, there are no known mechanisms that attempt to revert the insufficient cultural literacy, referring to the historical, epistemological and methodological aspects of geology, as well as the deficit in citizen literacy, which is reflected in the difficulties to identify main and secondary causes, or to recognize ethical conflicts in professional practices, or to express one's own ideas, taking into account different points of view. In short, I consider that such competencies limit the individuals to fully and actively participate in civic life.

Finally, a balance could be created: just as we wondered about the scientific geological literacy of citizens, we should also wonder about the scientific literacy of the scientists. This apparent play on words refers to the concept of literacy as a metaphor for the integral training of citizens that we have already considered as insufficient. This is why we can formulate some rhetorical questions that could help to think the challenges of the 21 st century:

- Why do the national universities and the national geology curricula not address the shortcomings in "civic" and "cultural" literacy, with the same dedication they have to overcoming practical literacy?

- How much better would be the training of geologists, how much better and more ethical could their professional practices and contributions to sustainable development be, if the dimensions of "civic" and "cultural" literacy were explicitly and formally incorporated in the curricula?

The answers to the above questions and their practical development will remain pending. However, some reflections and proposals are shared on some of the challenges that I believe will have to be assumed within the disciplinary field of geology, while interacting with other disciplinary fields.

The interaction between "geolodacts", teachers, academic authorities and provincial and national political officers will be essential to improve geological literacy in primary, secondary and higher education, in keeping with the 
complexity that is envisaged for the $21^{\text {st }}$ century.

\section{CONCLUSION : SOME CHALLENGES}

\subsection{Creating favorable instances for the devel- opment of geolodactics}

The scarce geological training of pre-university teachers and the lack of geolodactic resources often generate a certain degree of insecurity and fear for teaching geology. Thus, it is impossible to motivate students. This is a serious problem whose approach requires a number of specialists in geolodactics in a greater number than currently exists in Argentina. Consequently, the national universities have the social and political responsibility to favor the creation and development of geological research centers, as well as to incorporate researchers with exclusive dedication, from geology to pedagogy (Lacreu, 2107a). Training and updating of teachers is imperative to abandon the usual way to think of teaching geology and to replace it with new approaches that promote geologically significant learning. In that sense, we must work on the didactic transposition (Lacreu, 1996) and on the re-signification of geology as a historical science.

\subsection{Renewing the teaching of geology by em- phasizing the character of historical science}

Primary and secondary education should be renewed by incorporating approaches different than usual. On the one hand, meaningful learning should be promoted through school research, with and without field trips, problem solving or case studies. On the other hand, it is necessary to renew the epistemological approach and to develop strategies that allow one to understand the historical and interpretative character of geology (Frodeman, 1995). It has long been proposed that "geology is a historical science of nature, because it studies natural processes through forms (fossilized in the original) reflected in geological structures" (Potapova, 1968). In this sense, some experiences related to the construction of the geological history of landscape can be considered, both through fieldwork (Lacreu, 2007) and virtual classroom work (Lacreu, 2012b). In this way, attempts have been made to delete conceptual errors about the immutability of relief, its rocks and structures and to promote aw areness of the human impact on nature. Man leaves marks on the geological landscape, just as natural processes of the past have left marks that we can see today on the present landscape. The human marks are of a different nature, but their intensity is so strong as to suggest the introduction of a new geological epoch: the Anthropocene (Crutzen, 2002).

\subsection{Promoting epistemological coherence in the teaching of the natural sciences}

Natural sciences cannot be properly taught if geology is absent. This implies the reformulation of curricula at the pre-university level, university teaching formation, and training courses in natural sciences, so that geology can be incorporated as an inherent discipline in this group of sciences. This constitutes a political debt of university authorities (and a challenge for the geological community), that has been tolerated by action or omission. This permissiveness happens under the assumption that it is an educational problem, alien to geology, without realizing that its resolution inevitably requires the committed participation of geologists in general and geolodacts in particular. In this sense, in order to achieve an integrative teaching of the natural sciences, it is essential to use the historical approach, to highlight the fact that many of the biological, physical and chemical processes occurred in the past have been recorded in geological materials, in different times and places throughout the history of the Earth. These materials have undergone changes of shape and position and many of them contain mining resources necessary for society. Therefore, the search for new resources requires the historical reconstruction of geological land scapes.

\subsection{Promoting epistemological coherence in the teaching of the natural sciences}

The lack of access to civic and cultural geological literacy, as well as the scarce capability of writing and scientific communication, seriou sly 
threaten the achievement of the professional profile required by national regulations (Lacreu, 2017b). Consequently, curricula should recognize such shortcomings and explicitly incorporate compensatory strategies. For this purpose, the national universities commitment to society should be remembered: geology has been declared a discipline of public interest, because its professional practice can influence public safety, by putting risk on health, safety, rights, property or training of the inhabitants, as indicated in the Argentine regulations. It is necessary that students are progressively trained according to the national requirements of higher education for the 21st century (UNESCO, 2009), which particularly emphasizes the need for geologists to carry out their professional activities with a sense of ethical and social responsibility, and with the commitment to favour sustainable development.

\subsection{Contributing to sustainable development and to the clarification of its meaning}

Brundtland, in her first and valuable report (UN, 1987), proposes that Sustainable Development "is capable of responding to the needs of the present, without compromising the possibility of future generations to satisfy their needs". At the moment, it could seem a seductive but somewhat naive statement. In fact, it does not specify which social sectors are beneficiaries of the "needs of the present" and cannot anticipate what the needs of "future generations" will be. Besides, most environmental problems are the result of companies that define themselves as sustainable, but too often they only favor economic growth to the detriment of social equity and ecological balance. These situations require that geologists are aw are of the role (passive or active) that they can play in the creation/ solution of these problems (Lacreu, 2017b).

\section{REFERENCES}

Braslavsky B. (2003). Qué se entiende por alfabetización. Lectura y Vida. Año 24, 2:2-17.

Bybee R. (1997). Towards an Understanding of Scientific Literacy. In: Graeber W. and Bolte C. (Eds), Scientific Literacy, Kiel.
Crutzen P.J. (2002). Geology of Mankind. Nature, 415(6867), p. 23.

Fourez G. (1997). Alfabetización Científica y tecnológica. Acerca de las finalidades de la enseñanza de las ciencias, Ed Colihue, 255p.

Frodeman R. (1995). Geological reasoning: Geology as an interpretive and historical science. Geological Society of America Bulletin, 107(8):960-968.

Gil D. y Vilches, A. (2003). La contribución de la ciencia a la cultura ciudadana. Cultura y Educación, 16 (3):259-272, Valencia.

Gil Pérez D., Sifredo C., Valdés P. y Vilches A. (2005). ¿Cuál es la importancia de la educación científica en la sociedad actual? Santiago OREALC/ UNESCO:15-28.

Lacreu H.L. (1997). La transposición didáctica de las Geociencias. Enseñanza de las Ciencias de la Tierra, (5.1):37-48.

Lacreu H.L. (2007). La historia geológica del paisaje como contenido esencial en la enseñanza obligatoria. Alambique, N. 51:76-87.

Lacreu H.L. (2012a). Raíces políticas del analfabetismo geológico. XVII Simposio sobre Enseñanza de la Geología, Actas:91-99.

Lacreu H.L. (2012b). Recursos virtuales para la interpretación geológica del paisaje. Enseñanza de las Ciencias de la Tierra, Vol. 20.2: 198-202.

Lacreu H.L. (2014). Aciertos, distorsiones y falacias en la enseñanza de las ciencias naturales de la educación secundaria obligatoria de Argentina. Terræ Didatica 10-3:217-226, Campinas, Brasil.

Lacreu H.L. (2015). La geología en la educación primaria y secundaria. IBIGEO, Temas BGN oa Vol. 5, Núm. 2:25-28.

Lacreu H.L. (2017a). La enseñanza de la geología en el nivel preuniversitario. Ponencia en la Mesa redonda "Enseñanza de la geología” XX CGA, Tucumán unpublished.

Lacreu H.L. (2017b). Consecuencias sociales de las prácticas geológicas. Simposio Mirando al Futuro. XX CGA, Tucumán. Acta p. 3640.

Marco B. (2000). La alfabetización científica. En Perales, F. Y Cañal, P. (Eds.): Didáctica de las Ciencias Experimentales,141-164. Alcoi: Marfil.

Pedrinaci E., Alcalde S., Alfaro P., Almodóvar G.R., Barrera J.L., Belmonte A., Brusi D., 
Calonge A., Cardona V., Crespo-Blanc A., Feixas J.C., Fernández-Martínez E., González-Díez A., Jiménez-Millán J., López-Ruiz J., Mata-Perelló J.M., Pascual J.A., Quintanilla L., Rábano I., Rebollo L., Rodrigo A. y Roquero E. (2013). Alfabetización en Ciencias de la Tierra. Enseñanza de las Ciencias de la Tierra, 21.2., 117-129.

Potapova M.S. (1968). Geologia como uma ciência histórica da natureza. Terræ Didatica, 3(1):86-90.

UN (1987). Report of the World Commission on Environment and Development: Our Common Future. Chapter 2: Towards Sustainable Development, http:/ / www.undocuments.net/ w ced-ocf.htm (accessed 21 February 2018).

UNESCO (2009). La nueva dinámica de la educación superior y la investigación para el cambio social y el desarrollo. Comunicado de la Conferencia Mundial de la UNESCO, París..

[Figueredo and Wolf, 2009] Figueredo, A. J. and Wolf, P. S. A. (2009). Assortative pairing and life history strategy - a crosscultural study. Hum an Nature, 20:317-330.

[Figueredo and Wolf, 2009] Figueredo, A. J. and Wolf, P. S. A. (2009). Assortative pairing and life history strategy - a crosscultural study. Hum an Nature, 20:317-330. 